\title{
Larval phenologies and parasitoids of two seed- feeding weevils associated with hoary cress and shepherd's purse (Brassicaceae) in Europe
}

\author{
Franck J. Muller, Lloyd M. Dosdall, Peter G. Mason, Ulrich KuhImann
}

\begin{abstract}
In Europe, Ceutorhynchus turbatus Schultze and Ceutorhynchus typhae (Herbst) (Coleoptera: Curculionidae) feed on seeds from hoary cress and shepherd's purse (Cardaria draba (L.) Desv. and Capsella bursa-pastoris (L.) Medik.); both plants are invasive in North America. In North America, C. turbatus is a candidate for biological control of hoary cress, C. typhae is adventive, and both are sympatric with cabbage seedpod weevil (Ceutorhynchus obstrictus (Marsham)), an invasive alien pest of canola (Brassica napus L. and Brassica rapa L., Brassicaceae). We investigated host associations among C. turbatus, C. typhae, and their parasitoids in Europe. Of particular interest was host specificity of Trichomalus perfectus (Walker) and Mesopolobus morys (Walker) (Hymenoptera: Pteromalidae), candidates for biological control of C. obstrictus in North America. We found no evidence that $T$. perfectus attacks $C$. turbatus or $C$. typhae; however, $M$. morys was the most common parasitoid associated with C. turbatus.
\end{abstract}

\begin{abstract}
Résumé-En Europe, Ceutorhynchus turbatus Schultze et Ceutorhynchus typhae (Herbst) (Coleoptera : Curculionidae) se nourrissent des graines de la cardaire drave et de la capselle bourse-à-pasteur (Cardaria draba (L.) Desv. et Capsella bursa-pastoris (L.) Medik.), deux plantes envahissantes en Amérique du Nord. En Amérique du Nord, C. turbatus est un candidat pour la lutte biologique contre la cardaire drave, C. typhae est adventice et les deux espèces sont sympatriques avec le charançon de la graine du chou (Ceutorhynchus obstrictus (Marsham)), un ravageur exotique envahissant du colza (Brassica napus L. et Brassica rapa L., Brassicaceae). Nous avons étudié les associations d'hôtes entre $C$. turbatus, $C$. typhae et leurs parasitoïdes en Europe. La spécificité d'hôte de Trichomalus perfectus (Walker) et celle de Mesopolobus morys (Walker) (Hymenoptera : Pteromalidae) sont particulièrement intéressantes et ces espèces sont des candidats pour la lutte biologique contre C. obstrictus en Amérique du Nord. Nous n'avons aucune indication que $T$. perfectus attaque $C$. turbatus ou $C$. typhae; cependant, $M$. morys est le parasitoïde le plus communément associé à $C$. turbatus.
\end{abstract}

[Traduit par la Rédaction]

\section{Introduction}

Canada and the United States of America are currently working to combat invasions of two exotic pests, one arthropod and one weed, the control measures for which are linked. Cabbage seedpod weevil, Ceutorhynchus obstrictus (Marsham) (Coleoptera: Curculionidae: Ceutorhynchinae), is a pest of canola (oilseed rape), Brassica napus
L. (Brassicaceae), in Europe and was accidentally introduced to North America where it is now widespread (Kuhlmann et al. 2002). European hoary cress, Cardaria draba (L.) Desv. (Brassicaceae), is a widespread introduced weed in North America that is often found in habitats surrounding canola fields (Schwarzlaender et al. 2002; Fox and Dosdall 2003; Cripps et al. 2006). Ceutorhynchus obstrictus

Received 29 January 2011. Accepted 5 April 2011.

F.J. Muller, CABI Europe-Switzerland, Rue des Grillons 1, 2800 Delémont, Switzerland

L.M. Dosdall, ${ }^{1}$ Department of Agricultural, Food and Nutritional Science, University of Alberta, 4-10 Agriculture-Forestry Centre, Edmonton, Alberta, Canada T6G 2P5

P.G. Mason, Agriculture and Agri-Food Canada, Research Centre, 960 Carling Avenue, Ottawa, Ontario, Canada K1A 0C6

U. Kuhlmann, CABI Europe-Switzerland, Rue des Grillons 1, 2800 Delémont, Switzerland

${ }^{1}$ Corresponding author (e-mail: Lloyd.Dosdall@ales.ualberta.ca).

doi: $10.4039 / \mathrm{n} 11-020$ 
and hoary cress are currently controlled with chemical pesticides (Dosdall et al. 2001; Cárcamo et al. 2005; Anonymous 2011). Alternative control strategies are needed to reduce pesticide use and overcome difficulties in current management strategies.

Classical biological control for invasive alien species is cost-effective, permanent, selfsustaining, and ecologically safe when hostspecific agents are established (Wittenberg and Cock 2001). In Europe, C. obstrictus populations are suppressed by natural enemies, including the ectoparasitoids Trichomalus perfectus (Walker) and Mesopolobus morys (Walker) (Hymenoptera: Chalcidoidea: Pteromalidae), which may reduce populations of C. obstrictus by as much as $90 \%$ (Williams 2003). Both species were released in British Columbia in the 1950s but failed to establish (Gillespie et al. 2006), and they are being reevaluated for introduction to Canada (Kuhlmann et al. 2002, 2006).

Ceutorhynchus turbatus Schultze is widespread in natural habitats in Europe. Because it undergoes larval development within hoary cress siliques, it is being studied as a hoary cress biological control agent for potential introduction to North America (Cripps et al. 2006).

Hoary cress is a reservoir for various economically important pests in North America, including $C$. obstrictus (food source for adults) (Fox and Dosdall 2003; Dosdall and Moisey 2004; Cripps et al. 2006). Reducing populations of hoary cress should benefit C. obstrictus control by decreasing the availability of one of its food plants, especially in spring, when adults emerge from overwintering sites, until canola crops become suitable for adult feeding and larval development (Dosdall and Moisey 2004). However, introduction of $T$. perfectus and (or) M. morys to control $C$. obstrictus could affect control of hoary cress if lack of host specificity enables the parasitoids to attack $C$. turbatus. Another related nontarget seed-feeding species, Ceutorhynchus typhae (Herbst), could also be adversely affected. It is widespread in eastern Canada in Ontario, Quebec, New Brunswick, Nova Scotia, and Newfoundland (Bousquet 1991; Bouchard et al. 2005) and is associated with shepherd's purse, Capsella bursa-pastoris (L.) Medik.
(Brassicaceae), an economically important weed in canola and other crops in North America (Moss 1959; Budd and Best 1969). Consequently, these potential interactions must be considered when predicting nontarget effects of biological control agents for C. obstrictus.

Assessment of the potential impacts of C. obstrictus parasitoids on C. turbatus and $C$. typhae requires surveys to determine parasitoid assemblages associated with the hosts in their natural ranges. Such studies can also provide crucial host ecology information for use in selecting nontarget species for host-specificity testing and improving prediction of potential risks associated with introduction of biocontrol agents. Our objectives were to study $C$. typhae and $C$. turbatus to determine the $(i)$ phenologies of the species (and potential overlap with phenology of C. obstrictus), (ii) levels of parasitism of their larvae, and (iii) parasitoids associated with these two weevils in their native ranges in Europe.

\section{Materials and methods}

\section{Field collections of insects and plants (Table 1)}

Shepherd's purse and hoary cress plants were field collected in fallow fields, at field margins, or along road sides at various European localities from May to July 2003 and 2004. Surveys for C. typhae were made at seven sites in Germany, Switzerland, and France, where C. obstrictus is common. Ceutorhynchus turbatus specimens were collected at 14 sites in Switzerland and in two regions of Hungary where populations being evaluated for introduction to North America had been collected previously (Gassmann et al. 2001). Insect collections were made in wastelands or abandoned fields because the weevils are generally more abundant in those habitats than they are in recently disturbed sites.

Samples of 10-20 hoary cress or shepherd's purse plants were collected from each site on each sampling date with 2- to 10-day intervals between collections. Larvae of $C$. typhae and C. turbatus are morphologically indistinguishable but are specialists found in pods of shepherd's purse (Baur et al. 2007) and hoary cress (Cripps et al. 2006), respectively; thus, hostplant association was used to identify larvae of 
Table 1. Field collection site locations of shepherd's purse, Capsella bursa-pastoris, and hoary cress, Cardaria draba L. Desv., surveyed in 2003 and 2004 in Europe for the occurrence of Ceutorhynchus typhae and Ceutorhynchus turbatus, respectively.

\begin{tabular}{|c|c|c|c|c|c|}
\hline \multirow[b]{2}{*}{ Host plant / weevil species } & \multirow[b]{2}{*}{ Country } & \multirow[b]{2}{*}{ Region / Town } & \multirow{2}{*}{$\begin{array}{l}\text { Site } \\
\text { code }\end{array}$} & \multicolumn{2}{|c|}{ GPS coordinates } \\
\hline & & & & Lat. $\mathrm{N}$ & Long. E \\
\hline \multirow[t]{7}{*}{$\begin{array}{l}\text { Capsella bursa-pastoris / } \\
\text { Ceutorhynchus typhae }\end{array}$} & \multirow[t]{4}{*}{ Germany } & $\begin{array}{l}\text { Southern Rhine Valley / } \\
\text { Neuenburg* }\end{array}$ & 1 & $47^{\circ} 47^{\prime} 42.70^{\prime \prime}$ & $07^{\circ} 34^{\prime} 48.80^{\prime \prime}$ \\
\hline & & $\begin{array}{l}\text { Southern Rhine Valley / } \\
\text { Neuenburg* }\end{array}$ & 2 & $47^{\circ} 50^{\prime} 53.00^{\prime \prime}$ & $07^{\circ} 35^{\prime} 34.00^{\prime \prime}$ \\
\hline & & $\begin{array}{l}\text { Southern Rhine Valley / } \\
\text { Buggingen }^{\dagger}\end{array}$ & 3 & $47^{\circ} 51^{\prime} 30.93^{\prime \prime}$ & $07^{\circ} 36^{\prime} 59.91^{\prime \prime}$ \\
\hline & & $\begin{array}{l}\text { Southern Rhine Valley / } \\
\text { Zienken }\end{array}$ & 4 & $47^{\circ} 50^{\prime} 28.91^{\prime \prime}$ & $07^{\circ} 35^{\prime} 47.45^{\prime \prime}$ \\
\hline & \multirow[t]{2}{*}{ Switzerland } & Jura / Alle ${ }^{\dagger}$ & 5 & $47^{\circ} 26^{\prime} 11.79^{\prime \prime}$ & $07^{\circ} 08^{\prime} 31.07^{\prime \prime}$ \\
\hline & & Valais / Aproz ${ }^{\dagger}$ & 6 & $46^{\circ} 12^{\prime} 46.48^{\prime \prime}$ & $07^{\circ} 19^{\prime} 07.72^{\prime \prime}$ \\
\hline & France & Alsace / Boron ${ }^{\dagger}$ & 7 & $47^{\circ} 33^{\prime} 19.21^{\prime \prime}$ & $07^{\circ} 00^{\prime} 22.26^{\prime \prime}$ \\
\hline \multirow{14}{*}{$\begin{array}{l}\text { Cardaria draba / } \\
\quad \text { Ceutorhynchus turbatus }\end{array}$} & \multirow[t]{7}{*}{ Switzerland } & Valais / Chamoson* & 8 & $46^{\circ} 10^{\prime} 58.56^{\prime \prime}$ & $07^{\circ} 13^{\prime} 51.44^{\prime \prime}$ \\
\hline & & Valais / Ecône* & 9 & $46^{\circ} 10^{\prime} 28.87^{\prime \prime}$ & $07^{\circ} 12^{\prime} 54.19^{\prime \prime}$ \\
\hline & & Valais / Saxon* & 10 & $46^{\circ} 08^{\prime} 40.03^{\prime \prime}$ & $07^{\circ} 09^{\prime} 51.67^{\prime \prime}$ \\
\hline & & Valais / Aproz ${ }^{\dagger}$ & 11 & $46^{\circ} 12^{\prime} 46.48^{\prime \prime}$ & $07^{\circ} 19^{\prime} 07.72^{\prime \prime}$ \\
\hline & & Valais / Martigny $^{\dagger}$ & 12 & $46^{\circ} 06^{\prime} 36.49^{\prime \prime}$ & $07^{\circ} 06^{\prime} 12.82^{\prime \prime}$ \\
\hline & & Valais / Martigny $^{\dagger}$ & 13 & $46^{\circ} 06^{\prime} 47.04^{\prime \prime}$ & $07^{\circ} 06^{\prime} 54.24^{\prime \prime}$ \\
\hline & & Valais / Sion ${ }^{\dagger}$ & 14 & $46^{\circ} 13^{\prime} 11.80^{\prime \prime}$ & $07^{\circ} 20^{\prime} 43.09^{\prime \prime}$ \\
\hline & \multirow[t]{7}{*}{ Hungary } & $\begin{array}{l}\text { Csongrad / } \\
\text { Hödmezövasarhely }{ }^{\dagger}\end{array}$ & 15 & $46^{\circ} 24^{\prime} 50.80^{\prime \prime}$ & $20^{\circ} 00^{\prime} 03.24^{\prime \prime}$ \\
\hline & & $\begin{array}{l}\text { Csongrad / } \\
\text { Hödmezövasarhely }{ }^{\dagger}\end{array}$ & 16 & $46^{\circ} 24^{\prime} 45.24^{\prime \prime}$ & $20^{\circ} 17^{\prime} 21.66^{\prime \prime}$ \\
\hline & & $\begin{array}{l}\text { Csongrad / } \\
\text { Hödmezövasarhely }{ }^{\dagger}\end{array}$ & 17 & $46^{\circ} 15^{\prime} 41.62^{\prime \prime}$ & $20^{\circ} 12^{\prime} 24.52^{\prime \prime}$ \\
\hline & & Bekes / Kardoskut ${ }^{\dagger}$ & 18 & $46^{\circ} 16^{\prime} 41.41^{\prime \prime}$ & $20^{\circ} 19^{\prime} 34.25^{\prime \prime}$ \\
\hline & & Pest / Sari-Bugyi ${ }^{\dagger}$ & 19 & $47^{\circ} 12^{\prime} 09.12^{\prime \prime}$ & $19^{\circ} 13^{\prime} 50.22^{\prime \prime}$ \\
\hline & & Pest / Gyal ${ }^{\dagger}$ & 20 & $47^{\circ} 11^{\prime} 48.19^{\prime \prime}$ & $19^{\circ} 06^{\prime} 36.40^{\prime \prime}$ \\
\hline & & Pest / Sari-Bugyi ${ }^{\dagger}$ & 21 & $47^{\circ} 12^{\prime} 30.24^{\prime \prime}$ & $19^{\circ} 13^{\prime} 06.06^{\prime \prime}$ \\
\hline
\end{tabular}

*Collections made in 2003.

Collections made in 2004.

each species. Twenty pods per plant were dissected to detect weevil eggs and larvae; larvae were then determined to instar. Mature third instars of both species leave seed pods to pupate in soil. Thus, pod exit hole counts were also used for estimating numbers of third-instar larvae.

\section{Estimates of parasitism level}

For each plant dissected, parasitoid eggs and larvae found on or near host larvae and pupae found near host bodies were recorded to estimate parasitism levels on each collection date for every field site. Mortality due to host feeding by parasitoid adults (as evidenced, e.g., by brownish punctures on larval integument) was recorded separately as an indirect effect of parasitism. Parasitism was calculated for each site as follows:

$$
\begin{aligned}
& \% \text { Parasitism }=\frac{\sum_{1}^{n} \text { paras. }}{\sum_{1}^{n} \text { avail.hosts }} \times 100 \\
& =\frac{\sum_{\text {larv }}{ }^{\text {par }}+\sum_{\text {larv }}{ }^{\dagger}+\sum_{\text {par }}^{\text {alone }}}{\sum_{\text {larv }}^{\text {healthy }}+\sum_{\text {larv }}{ }^{p^{2}+\sum_{\text {larv }}+\sum_{\text {holes }}+\sum_{\text {par }}^{\text {alone }}}} \\
& \times 100
\end{aligned}
$$

where $\Sigma_{1}^{n}$ paras. and $\Sigma_{1}^{n}$ avail.hosts are the total numbers within a plant of parasitoids and 
of hosts (second- and third-instar larvae) available for parasitism, respectively; $\Sigma_{\text {larv }}{ }^{\text {par }}$ and $\Sigma_{\operatorname{larv}^{\dagger}}^{\dagger}$ are the numbers of parasitized larvae and of dead larvae with traces of host feeding, respectively; $\Sigma_{\text {par }}$ alone is the number of parasitoids (pupae and newly eclosed adults) found alone near dead hosts; $\Sigma_{\text {larv }}$ healthy is the number of healthy host larvae; and $\Sigma_{\text {holes }}$ is the number of exit holes found on shoots or pods during dissections.

A representative parasitism level was estimated for each site on the date when the maximum number of larvae still available for parasitism was present in the plant (i.e., just before exit holes appeared in the pods). Host density was determined by considering the maximum number of hosts parasitized or available for parasitism during the season. Only second- and third-instar larvae were used for calculations. At high larval infestation levels, a maximum of two larvae can develop within the same pod, but they are separated from each other by a partition (replum). Occasionally, two third-instar larvae may exit a plant through the same hole; this may have led to a slight under-estimation of larval numbers.

\section{Parasitoids}

Parasitoids were reared on filter paper discs in $5.5 \mathrm{~cm}$ diameter Petri dishes in a controlledenvironment chamber at $20 \pm 2{ }^{\circ} \mathrm{C}, 70 \% \pm$ $10 \% \mathrm{RH}$, and 16L:8D and were checked daily until emergence of adults. Parasitoid eggs and larvae were reared on the host larvae upon which they were collected; pupae were reared individually. Adults were killed with ethyl acetate, card-mounted, and labelled. Voucher specimens were deposited in the Natural History Museum of Bern, Switzerland; the Canadian National Collection of Insects, Ottawa, Canada; the National Museum of Natural History, Washington D.C., United States of America; and at CABI Europe-Switzerland, Delémont, Switzerland.

\section{Results}

\section{Ceutorhynchus typhae on shepherd's purse}

Phenological data for $C$. typhae are presented for three study sites for 2003 (Fig. 1).
Some phenological characteristics of C. typhae varied between sites and years, apparently in relation to the developmental biology of shepherd's purse. Shepherd's purse flowered throughout the season, so fresh pods were available until late summer (Muller 2006). Nevertheless, some weevil phenological trends were consistent across sites and years. For instance, eggs of $C$. typhae were laid from May to the end of June, but egg numbers declined from early to late in the sampling period as a proportion of all life stages observed. Eggs typically comprised more than $70 \%$ of all life stages in May to early June, but declined to less than $10 \%$ by the end of June. First-instar larvae were present in pods of shepherd's purse on every sampling date from mid-May onwards; their proportion of all life stages present usually did not decline over time. Numbers of second and third instars increased beginning in the third week of May, and densities ranged from $0.15 \pm 0.08$ larvae per plant in the southern Rhine Valley of Germany (site 4) to $4.60 \pm 0.29$ in the Swiss Jura near Alle (site 5) (Table 2). Third-instar larvae were first found in early to mid-June, and mature larvae began to exit plants beginning in the second week of June (Fig. 1).

\section{Parasitoids associated with Ceutorhynchus typhae}

Parasitoids were observed within siliques of shepherd's purse for about 3 weeks beginning in the first week of June (Fig. 1). Parasitism increased over time at most (e.g., sites 1, 5), but not all (e.g., site 7) sites (Fig. 1). In Germany, parasitism was highest at site 2 near Neuenburg in the southern Rhine Valley (Table 2). In Switzerland, parasitism reached a maximum of $59.5 \%$ at site 5 near Alle, in the Swiss Jura on 21 June 2003, and parasitism at the site in France was $16.7 \%$.

Thirty-eight specimens of Mesopolobus gemellus Baur and Muller (37) and Stenomalina gracilis (Walker) (1) (Hymenoptera: Pteromalidae) were reared in association with C. typhae. Mesopolobus gemellus oviposited on late-instar larvae of C. typhae in May and June. Adults of the new generation emerged and left the senesced pods in late June of the same year. 
Fig. 1. Proportions of eggs, larval instars 1-3, parasitism, and exit holes (egression of mature larvae) of Ceutorhynchus typhae in Germany, Southern Rhine Valley, Neuenburg (site 1), Switzerland, Jura, Alle (site 5), and France, Alsace, Boron (site 7) between May and July 2003.

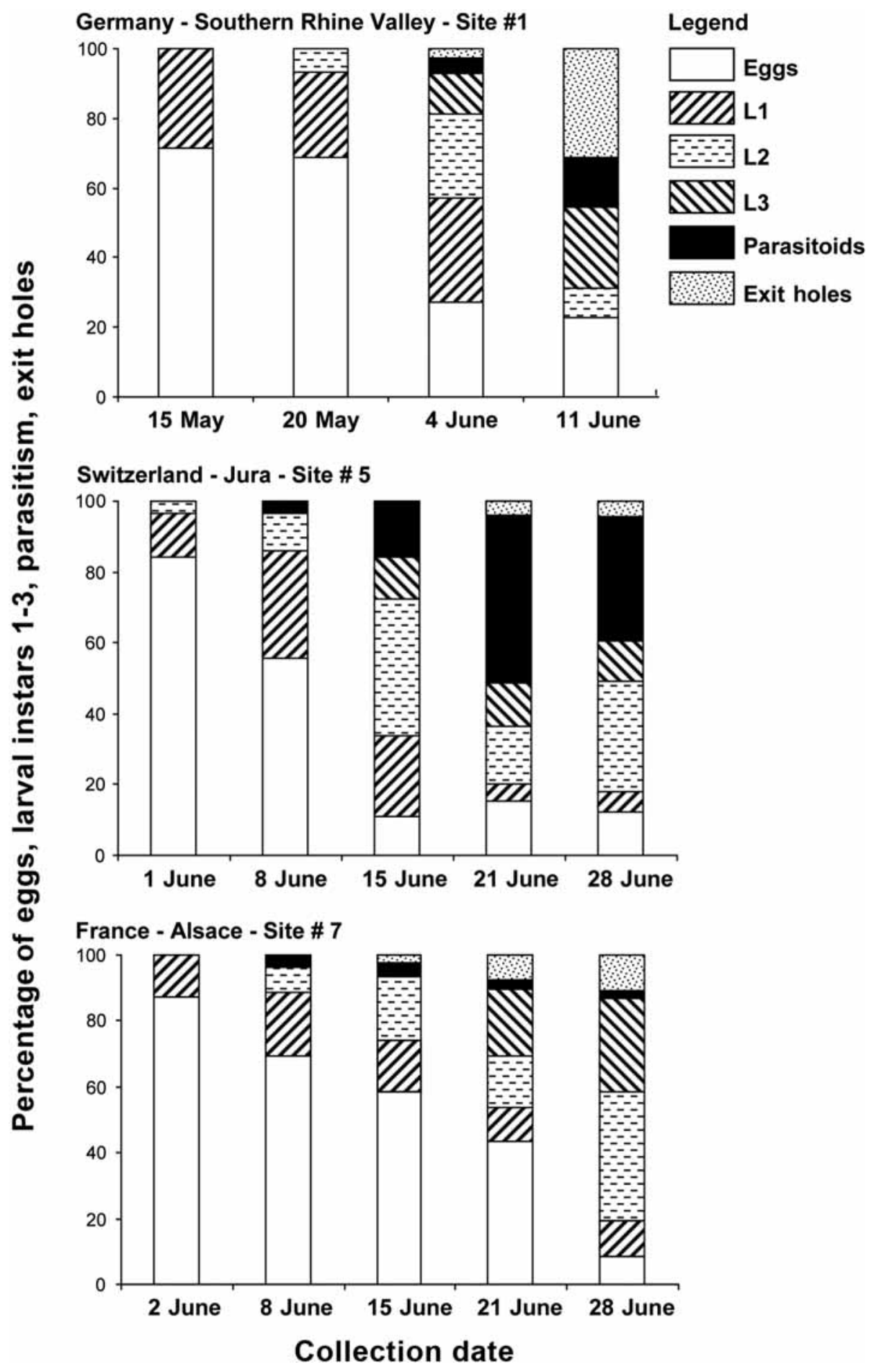


Table 2. Mean numbers ( \pm SE) of second- and third-instar larvae of Ceutorhynchus typhae available for parasitism and percent parasitism observed in Germany, Switzerland, and France in 2003 and 2004.

\begin{tabular}{|c|c|c|c|c|c|}
\hline Country & Location & Site code & Plants dissected & $\begin{array}{c}\text { Mean }( \pm \text { SE }) \\
\text { larvae per plant }\end{array}$ & Parasitism (\%) \\
\hline \multirow[t]{4}{*}{ Germany } & $\begin{array}{l}\text { Southern Rhine } \\
\text { Valley / Neuenburg* }\end{array}$ & 1 & 160 & $1.58(0.45)$ & 10.0 \\
\hline & $\begin{array}{l}\text { Southern Rhine } \\
\text { Valley / Neuenburg* }\end{array}$ & 2 & 160 & $3.05(0.44)$ & 11.5 \\
\hline & $\begin{array}{l}\text { Southern Rhine } \\
\text { Valley / Buggingen }{ }^{\dagger}\end{array}$ & 3 & 160 & 0.00 & 0.0 \\
\hline & $\begin{array}{l}\text { Southern Rhine } \\
\text { Valley / Zienken }\end{array}$ & 4 & 160 & $0.15(0.08)$ & 0.0 \\
\hline \multirow[t]{2}{*}{ Switzerland } & Jura / Alle $e^{\dagger}$ & 5 & 200 & $4.60(0.29)$ & 59.5 \\
\hline & Valais / Aproz & 6 & 200 & $1.85(0.33)$ & 15.0 \\
\hline France & Alsace / Boron ${ }^{\dagger}$ & 7 & 200 & $1.85(0.15)$ & 16.7 \\
\hline
\end{tabular}

\section{Ceutorhynchus turbatus on hoary cress}

Phenological data for C. turbatus are presented for two study sites for 2004 (Fig. 2). As for C. typhae, phenological details varied somewhat across sites and years, but some observations were consistent. Eggs of C. turbatus typically comprised greater than $90 \%$ of all life stages from early to late May. First-instar larvae were first observed from the last week of May to the first week of June; second-instar larvae were present beginning in the second week of June. Densities of second and third instars per plant in the Swiss Valais ranged from $0.75 \pm 0.23$ at Aproz (site 11) to $11.25 \pm 0.64$ at Sion (site 14) (Table 3). In Hungary, densities tended to be lower on average at all sites surveyed, with a maximum of $7.50 \pm 0.70$ secondand third-instar larvae per plant observed at site 15 near Hödmezövasarhely and a minimum of no larvae at another site near the same town (site 16) (Table 3). Mean densities of second and third instars per plant in 2003 and 2004 were $6.8 \pm 1.7$ in Switzerland and $2.1 \pm 1.6$ in Hungary.

\section{Parasitoids associated with Ceutorhynchus turbatus}

Parasitoids were present earlier in the season in Hungary than in Switzerland at all sites surveyed. In 2004, parasitism was first evident in the second week of June in Hungary, as soon as secondinstar larvae were observed; in the Swiss Valais, parasitism was first evident in the last week of June (Fig. 2). All larvae had exited plants by 24 June 2004 in Hungary at site 20 near Gyal; at the same time in Switzerland, all larval instars were found in plants. Parasitism levels in Switzerland ranged from $15.4 \%$ to $80.0 \%$ in 2003 , and $18.2 \%$ to $44.0 \%$ in 2004. Similar parasitism levels $(11.1 \%-41.8 \%)$ were observed in Hungary, except for site 18 near Hödmezövasarhely, where no parasitoids were found.

Ten chalcidoid species (Table 4) were associated with $C$. turbatus collected from hoary cress: Eurytoma curculionum Mayr (Eurytomidae), Mesopolobus morys (Walker), Pteromalus sequester Walker, and Trichomalus cf. perfectus (Walker) (Pteromalidae), as well as an unidentified species of each of Baryscapus Förster and Closterocerus Westwood (Eulophidae), Eupelmus Dalman (Eupelmidae), Pteromalus Swederus, Syntomopus Walker, and Trichomalus Thomson (Pteromalidae). Parasitoid species compositions varied considerably among sites, with $M$. morys found at all sites except site 16 in Hungary (Table 4). None of the parasitoids of $C$. turbatus were confirmed as $T$. perfectus.

\section{Discussion}

Distributions of the three weevil species, C. obstrictus, C. typhae, and C. turbatus, are sympatric in Europe (Bonnemaison 1957; Cripps et al. 2006), and our observations indicate 
Fig. 2. Proportions of eggs, larval instars 1-3, parasitism, and exit holes (egression of mature larvae) of Ceutorhynchus turbatus in Sion, Valais, Switzerland (site 14) and Gyal, Pest, Hungary (site 20) between May and July 2004.

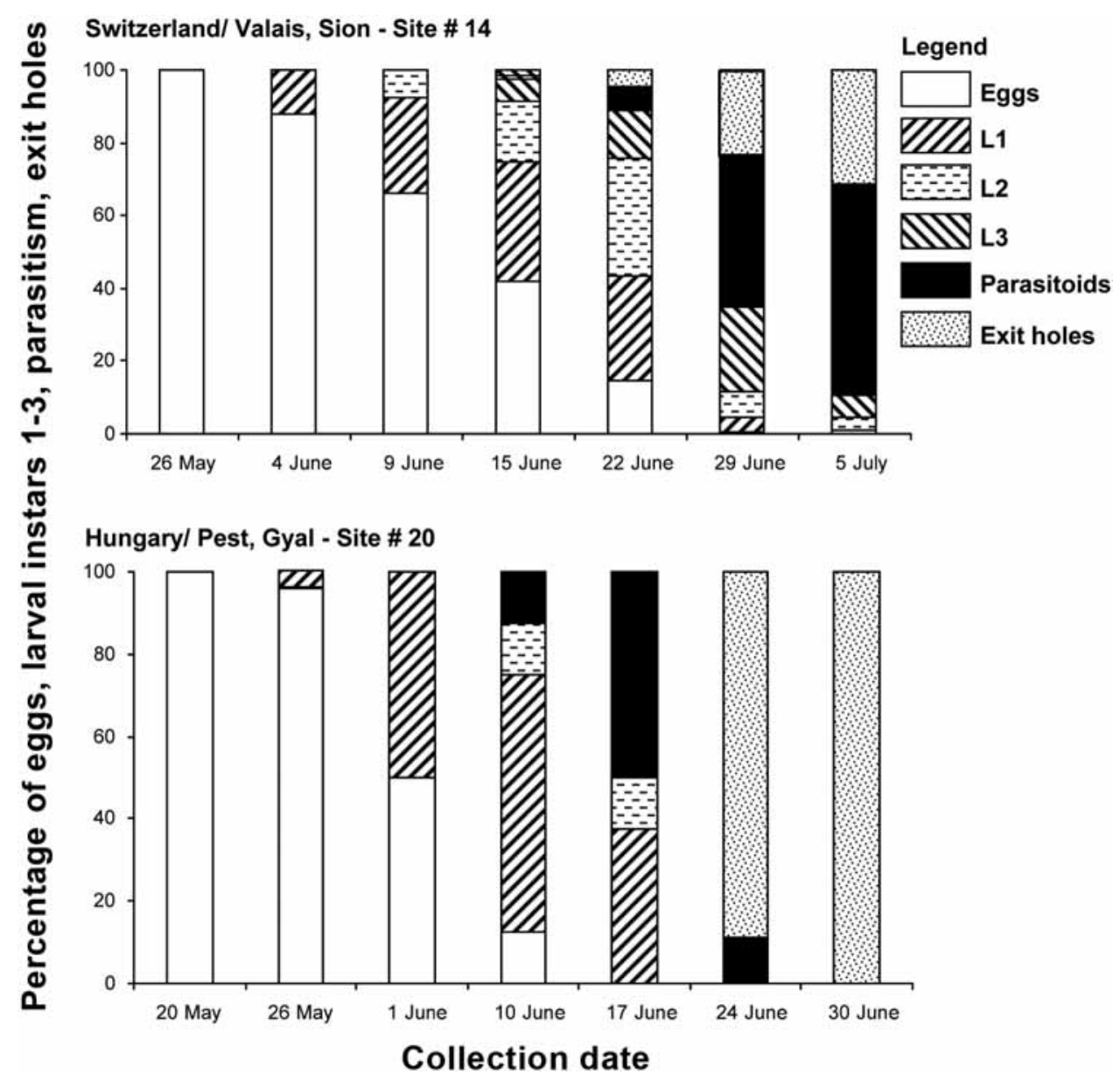

that some overlap also occurs in their phenological development. For instance, females of C. turbatus and C. typhae oviposit in pods of their host plants during May and June. Larvae develop through three instars and, when mature, each chews a hole in its pod wall, drops to the ground, and pupates in the soil. Weevils of the new generation emerge during June and July of the same year. Both species overwinter as adults and resume activity the following spring. Larvae of C. obstrictus also develop from May through July (Bonnemaison 1957; Dosdall and Moisey 2004), confirming that their pre-imaginal development coincides temporally with that of larvae of C. turbatus and C. typhae in the field.

Host-plant phenologies also overlap in Europe and North America. On both continents, shepherd's purse can overwinter as a seedling or a seed, and flowering occurs from March to June or July (Defelice 2001; Iannetta et al. 2007). Hoary cress flowers from March to July in Europe and North America (Mulligan and Findlay 1974; Larina 2003), a period overlapping with the range of flowering time of canola on the two continents (Lefol et al. 1996; Thomas 2002). As a consequence of this phenological overlap, C. turbatus and C. typhae could be attacked by a nonhost-specific 
Table 3. Mean numbers ( \pm SE) of second- and third-instar larvae of Ceutorhynchus turbatus available for parasitism and percent parasitism observed in Switzerland and Hungary in 2003 and 2004.

\begin{tabular}{|c|c|c|c|c|c|}
\hline Country & Location & $\begin{array}{l}\text { Site } \\
\text { code }\end{array}$ & $\begin{array}{c}\text { Plants } \\
\text { dissected }\end{array}$ & $\begin{array}{c}\text { Mean }( \pm \text { SE }) \\
\text { larvae per plant }\end{array}$ & Parasitism ( $\%)$ \\
\hline \multirow[t]{7}{*}{ Switzerland } & Valais / Chamoson* & 8 & 70 & $3.90(0.42)$ & 15.4 \\
\hline & Valais / Ecône* & 9 & 70 & $1.88(0.36)$ & 80.0 \\
\hline & Valais / Saxon* & 10 & 140 & $9.15(0.21)$ & 39.8 \\
\hline & Valais / Aproz ${ }^{\dagger}$ & 11 & 140 & $0.75(0.23)$ & 18.2 \\
\hline & Valais / Martigny $^{\dagger}$ & 12 & 140 & $10.50(0.72)$ & 19.9 \\
\hline & Valais / Martigny $^{\dagger}$ & 13 & 140 & $10.10(1.02)$ & 32.8 \\
\hline & Valais / Sion ${ }^{\dagger}$ & 14 & 140 & $11.25(0.64)$ & 44.0 \\
\hline \multirow[t]{7}{*}{ Hungary } & $\begin{array}{l}\text { Csongrad / } \\
\text { Hödmezövasarhely }{ }^{\dagger}\end{array}$ & 15 & 140 & $7.50(0.70)$ & 25.6 \\
\hline & $\begin{array}{l}\text { Csongrad / } \\
\text { Hödmezövasarhely }\end{array}$ & 16 & 140 & $0.00(0.00)$ & 0.0 \\
\hline & $\begin{array}{l}\text { Csongrad / } \\
\text { Hödmezövasarhely }\end{array}$ & 17 & 140 & $3.35(0.40)$ & 41.8 \\
\hline & Bekes / Kardoskut ${ }^{\dagger}$ & 18 & 140 & $1.15(0.27)$ & 28.6 \\
\hline & Pest / Sari-Bugyi ${ }^{\dagger}$ & 19 & 140 & $1.15(0.31)$ & 33.3 \\
\hline & Pest / Gyal ${ }^{\dagger}$ & 20 & 140 & $0.90(0.26)$ & 11.1 \\
\hline & Pest / Sari-Bugyi ${ }^{\dagger}$ & 21 & 140 & $0.70(0.21)$ & 21.4 \\
\hline
\end{tabular}

*Collections made in 2003.

${ }^{\dagger}$ Collections made in 2004.

parasitoid introduced for biological control of C. obstrictus.

The phenologies of larval parasitoids collected from $C$. turbatus and $C$. typhae were closely linked with host phenologies. All parasitoids encountered during our surveys oviposited on late-instar host larvae. Parasitoid larvae fed on their hosts for 2-4 weeks and pupated within the siliques. Pupation required 1-2 weeks, and adults of the new parasitoid generation emerged through openings in the senesced pods. This development occurred primarily from early to late June (on C. typhae) and mid-June to early July (on $C$. turbatus) (Figs. 1, 2), a period that coincides with the development of $T$. perfectus and $M$. morys on C. obstrictus (Williams 2003; Baur et al. 2007; Muller et al. 2007).

The parasitoid assemblage associated with C. typhae was considerably less diverse than that of C. turbatus. Mesopolobus gemellus was responsible for $98 \%$ of $C$. typhae parasitism at all sites studied, and only a single specimen of another parasitoid, S. gracilis, was reared from this host. On average, approximately $25 \%$ of all C. typhae hosts were parasitized. Because all
C. typhae life stages were present when sampling was terminated (Fig. 1), it is possible that additional parasitoid species that attack later in the season were missed in our study. Mesopolobus gemellus appears to be host specific in C. typhae: Baur et al. (2007) reared many specimens from $C$. typhae but only a single female (of questionable identity) from C. turbatus. By contrast, S. gracilis has a broad host range, reported from approximately 25 host species including C. obstrictus and several other ceutorhynchine weevils (Dosdall et al. 2009).

In contrast to C. typhae on shepherd's purse, C. turbatus on hoary cress had a more diverse parasitoid assemblage with 10 species recovered. Mesopolobus morys, a candidate agent for $C$. obstrictus biological control, was the most common parasitoid of $C$. turbatus and accounted for approximately $40 \%$ of total C. turbatus parasitism. This species was also widespread, occurring at almost all sites in Switzerland and Hungary where $C$. turbatus was collected on hoary cress. Pteromalus sequester, the second most important larval parasitoid attacking $C$. turbatus, represented $37 \%$ of the parasitoid assemblage and was 
Table 4. Parasitoid species and the percent compositions of parasitoids associated with Ceutorhynchus turbatus at each European sample site in 2003 and 2004.

\begin{tabular}{|c|c|c|c|c|}
\hline Year & Site & Parasitoid species & No. of individuals & Percentage \\
\hline \multirow[t]{5}{*}{2003} & Switzerland / Valais-site 10 & Mesopolobus morys* & 34 & 100.0 \\
\hline & \multirow[t]{2}{*}{ Switzerland / Valais-site 9} & M. morys* & 2 & 66.7 \\
\hline & & $\begin{array}{l}\text { Pteromalus } \\
\quad \text { sequester } \mathrm{gr}^{*}\end{array}$ & 1 & 33.3 \\
\hline & \multirow[t]{2}{*}{ Switzerland / Valais-site 14} & M. morys* & 4 & 57.1 \\
\hline & & P. sequester $\mathrm{gr}^{*}$ & 3 & 42.9 \\
\hline \multirow[t]{39}{*}{2004} & Switzerland / Valais-site 11 & P. sequester $\mathrm{gr}^{*}$ & 2 & 100.0 \\
\hline & \multirow[t]{2}{*}{ Switzerland / Valais-site 12} & M. morys* & 13 & 86.7 \\
\hline & & P. sequester $\mathrm{gr}^{*}$ & 2 & 13.3 \\
\hline & \multirow[t]{2}{*}{ Switzerland / Valais-site 13} & P. sequester $\mathrm{gr}^{*}$ & 20 & 52.6 \\
\hline & & M. morys* & 18 & 47.4 \\
\hline & \multirow[t]{3}{*}{ Switzerland / Valais-site 14} & P. sequester $\mathrm{gr}^{*}$ & 27 & 55.1 \\
\hline & & M. morys* & 21 & 42.9 \\
\hline & & Eupelmus sp. ${ }^{\S}$ & 1 & 2.0 \\
\hline & \multirow[t]{4}{*}{ Hungary / Csongrad-site 15} & M. morys* & 14 & 50.0 \\
\hline & & P. sequester $\mathrm{gr}^{*}$ & 11 & 39.2 \\
\hline & & Baryscapus sp..$^{\dagger}$ & 2 & 7.2 \\
\hline & & Eupelmus $\mathrm{sp.}^{\S}$ & 1 & 3.6 \\
\hline & \multirow[t]{2}{*}{ Hungary / Csongrad-site 16} & Baryscapus sp..$^{\dagger}$ & 1 & 50.0 \\
\hline & & $P$. sequester $\mathrm{gr}^{*}$ & 1 & 50.0 \\
\hline & \multirow{11}{*}{ Hungary / Csongrad-site 17} & P. sequester $\mathrm{gr}^{*}$ & 20 & 29.4 \\
\hline & & Closterocerus sp. ${ }^{\dagger}$ & 13 & 19.1 \\
\hline & & Baryscapus $\mathrm{sp}^{\dagger}$ & 10 & 14.7 \\
\hline & & Eurytoma curculionum & 8 & 11.8 \\
\hline & & M. morys* & 8 & 11.8 \\
\hline & & Eupelmus sp. ${ }^{\S}$ & 2 & 2.9 \\
\hline & & $\begin{array}{l}\text { Trichomalus cf. } \\
\text { perfectus* }\end{array}$ & 2 & 2.9 \\
\hline & & Trichomalus sp.* & 2 & 2.9 \\
\hline & & E. curculionum ${ }^{*}$ & 1 & 1.5 \\
\hline & & Pteromalus sp.* & 1 & 1.5 \\
\hline & & Syntomopus sp.* & 1 & 1.5 \\
\hline & \multirow[t]{5}{*}{ Hungary / Bekes-site 18} & P. sequester gr* & 11 & 61.1 \\
\hline & & Closterocerus sp..$^{\dagger}$ & 4 & 22.2 \\
\hline & & Baryscapus sp..$^{\dagger}$ & 1 & 5.6 \\
\hline & & E. curculionum & 1 & 5.6 \\
\hline & & Eupelmus sp. ${ }^{\S}$ & 1 & 5.6 \\
\hline & \multirow[t]{2}{*}{ Hungary / Sari-site 19} & M. morys* ${ }^{*}$ & 2 & 50.0 \\
\hline & & P. sequester $\mathrm{gr}^{*}$ & 2 & 50.0 \\
\hline & \multirow[t]{3}{*}{ Hungary / Gyal-site 20} & P. sequester $\mathrm{gr}^{*}$ & 2 & 50.0 \\
\hline & & Eupelmus sp. ${ }^{\S}$ & 1 & 25.0 \\
\hline & & M. morys* & 1 & 25.0 \\
\hline & \multirow{4}{*}{ Hungary / Sari-site 21} & M. morys* & 2 & 40.0 \\
\hline & & Closterocerus sp. ${ }^{\dagger}$ & 1 & 20.0 \\
\hline & & E. curculionum $^{*}$ & 1 & 20.0 \\
\hline & & P. sequester $\mathrm{gr}^{*}$ & 1 & 20.0 \\
\hline
\end{tabular}

*Chalcidoidea: Pteromalidae.

${ }^{\dagger}$ Chalcidoidea: Eulophidae.

Chalcidoidea: Eurytomidae.

${ }^{\S}$ Chalcidoidea: Eupelmidae. 
also present at nearly all sites studied. Our rearing of Eurytoma curculionum, previously associated with C. obstrictus (Dmoch 1975), is the first record of its association with C. turbatus on hoary cress. Interestingly, although this parasitoid is known to occur in France (Thompson 1955; Herting 1973) and Germany (Freese 1995; Vidal 1997), we only observed it on $C$. turbatus in Hungary. Several other parasitoid species (e.g., Closterocerus sp., Baryscapus sp., Trichomalus sp., Pteromalus sp., and Syntomopus sp.) were also encountered only in Hungary during our surveys and species of these genera have not previously been associated with $C$. turbatus. Two specimens of Trichomalus cf. perfectus were collected, together representing less than $1 \%$ of all parasitoids obtained during our surveys.

Concerns regarding nontarget effects in arthropod biological control are well documented (Howarth 1991; Simberloff and Stiling 1996; Thomas and Willis 1998; Stiling and Simberloff 2000; Louda et al. 2003; Stiling 2004). Consequently, new methods to assess the risks associated with the introduction of non-native species for biological control of arthropods have been proposed (Babendreier et al. 2005; Simberloff 2005; Wright et al. 2005; Kuhlmann et al. 2006). It is clear that the pre-imaginal development of ceutorhynchine weevils that comprise pest ( $C$. obstrictus), adventive (C. typhae), and potential weed biocontrol agents $(C$. turbatus) overlap, and increased risk to the nontarget species is associated with release of biological agents for control of $C$. obstrictus unless the agents are host specific. Mesopolobus morys, an important parasitoid of C. obstrictus (Williams 2003), was the most common species parasitizing C. turbatus in Switzerland and Hungary. In the event of separate introductions of $M$. morys and $C$. turbatus as biocontrol agents against $C$. obstrictus and hoary cress, respectively, potential conflicts might occur between the two programmes. In contrast, because $T$. perfectus appears to be host specific and does not attack $C$. turbatus or $C$. typhae, this species should pose minimal risk if it is introduced in Canada for biological control of C. obstrictus. Therefore, to avoid conflicts with weed biological control our results suggest that further evaluation of $T$. perfectus for classical biological control of $C$. obstrictus would be appropriate.

\section{Acknowledgments}

We thank E. Cuenot, V. Larraz, L. Lovis, G. Nagy, F. Janos, A. Leroux, and L. Andreassen for technical assistance in the field and laboratory. We thank H. Hinz and S. Toepfer for helpful advice and information on collection sites of $C$. draba in various European countries. Hannes Baur (Natural History Museum, Bern, Switzerland) and Gary Gibson (Canadian National Collection, Ottawa, Ontario) provided pteromalid identifications, Michael Gates (United States Department of Agriculture, Agriculture Research Service, National Museum of Natural History, Washington D.C.) identified the eurytomids. This work was funded by Agriculture and Agri-Food Canada, its Pest Management Research Centre Project PRR03-370, and the Alberta Agricultural Research Institute.

\section{References}

Anonymous. 2011. Whitetop/hoary cress Cardaria draba (L.) Desv. [online]. Available from http:// parks.state.co.us/SiteCollectionImages/parks/ Programs/ParksResourceStewardship/Whitetop. pdf [accessed 21 March 2011].

Babendreier, D., Bigler, F., and Kuhlmann, U. 2005. Methods used to assess non-target effects of invertebrate biological control agents of arthropod pests. BioControl, 50: 821-870. doi:10. 1007/s10526-005-3633-3.

Baur, H., Muller, F.J., Gibson, G.A.P., Mason, P.G., and Kuhlmann, U. 2007. A review of the species of Mesopolobus (Chalcidoidea: Pteromalidae) associated with Ceutorhynchus (Coleoptera: Curculionidae) host-species of European origin. Bulletin of Entomological Research, 97: 387-397. doi:10.1017/S0007485307005032.

Bonnemaison, L. 1957. Le charançon des siliques (Ceutorhynchus assimilis Payk.) Biologie et Méthodes de lutte. Annales de l'institut national de la recherche agronomique-Serie C: Annales des Epiphyties, 8: $387-542$.

Bouchard, P., Lesage, L., Goulet, H., Bostanian, N.J., Vincent, C., Zmudzinska, A., and Lasnier, J. 2005. Weevil (Coleoptera: Curculionoidea) diversity and abundance in two Québec vineyards. Annals of the Entomological Society of America, 98: 565-574. doi:10.1603/0013-8746 (2005)098[0565:WCCDAA]2.0.CO;2.

Bousquet, Y. 1991. Checklist of beetles of Canada and Alaska. Agriculture Canada Publication, 1861/E. 
Budd, A.C., and Best, K.F. 1969. Wild plants of the Canadian prairies. Canada Department of Agriculture Research Branch Publication, 983.

Cárcamo, H.A., Dosdall, L.M., Johnson, D., and Olfert, O. 2005. Evaluation of foliar and seed treatments for control of the cabbage seedpod weevil (Coleoptera: Curculionidae) in canola. The Canadian Entomologist, 137: 476-487. doi:10.4039/n04-081.

Cripps, M.G., Hinz, H.L., McKenney, J.L., Harmon, B.L., Merickel, F.W., and Schwarzlaender, M. 2006. Comparative survey of the phytophagous arthropod faunas associated with Lepidium draba in Europe and the western United States, and the potential for biological weed control. Biocontrol Science and Technology, 16: 10071030. doi:10.1080/09583150600828361.

Defelice, M.S. 2001. Shepherd's purse, Capsella bursapastoris (L.) Medic. Weed Technology, 15: 892-895. doi:10.1614/0890-037X(2001)015[0892:SSPCBP]2. $0 . \mathrm{CO} ; 2$.

Dmoch, J. 1975. Study on the parasites of the cabbage seedpod weevil (Ceutorhynchus assimilis Payk.). I. Species composition and economic importance of the larval ectoparasites. Roczniki Nauk Rolniczych, 5: 99-112.

Dosdall, L.M., and Moisey, D.W.A. 2004. Developmental biology of the cabbage seedpod weevil, Ceutorhynchus obstrictus (Coleoptera: Curculionidae), in spring canola, Brassica napus, in western Canada. Annals of the Entomological Society of America, 97: 458-465. doi:10.1603/00138746(2004)097[0458:DBOTCS]2.0.CO;2.

Dosdall, L.M., Moisey, D., Cárcamo, H.A., and Dunn, R. 2001. Cabbage seedpod weevil fact sheet. Alberta Agriculture, Food and Rural Development Agdex, 622-621: 1-4.

Dosdall, L.M., Gibson, G.A.P., Olfert, O., and Mason, P.G. 2009. Responses of Chalcidoidea (Hymenoptera) parasitoids to invasion of the cabbage seedpod weevil (Coleoptera: Curculionidae) in western Canada. Biological Invasions, 11: 109-125. doi:10.1007/s10530-008-9323-1.

Fox, A.S., and Dosdall, L. 2003. Reproductive biology of Ceutorhynchus obstrictus (Coleoptera: Curculionidae) on wild and cultivated Brassicaceae in southern Alberta. Journal of Entomological Science, 38: 533-544.

Freese, G. 1995. Structural refuges in two stem-boring weevils on Rumex crispus. Ecological Entomology, 20: 351-358. doi:10.1111/j.1365-2311. 1995.tb00467.x.

Gassmann, A., Hinz, H.L., de Meij, A., Heinlein, G., Spiewak, E., and Yaworski, K. 2001. Whitetop or hoary cress (Cardaria spp.). CABI Bioscience Switzerland Centre, Weed Biological Control Quarterly Report. pp. 25-27.

Gillespie, D.R., Mason, P.G., Dosdall, L., Bouchard, P., and Gibson, G.A.P. 2006. Importance of long-term research in classical biological control: An analytical review of a release against the cabbage seedpod weevil in North America. Journal of Applied Entomology, 130: 401-409. doi:10.1111/j.1439-0418.2006.01085.x.

Herting, B. 1973. Coleoptera to Strepsiptera. Section A. Host or prey/enemy. In A catalogue of parasites and predators of terrestrial arthropods. Commonwealth Agricultural Bureaux. Institute of Biological Control, Farnham Royal, Slough, United Kingdom.

Howarth, F.G. 1991. Environmental impacts of classical biological control. Annual Review of Entomology, 36: 485-509. doi:10.1146/annurev. en.36.010191.002413

Iannetta, P.P.M., Begg, G., Hawes, C., Young, M., Russell, J., and Squire, G.R. 2007. Variation in Capsella (shepherd's purse): An example of intraspecific functional diversity. Physiologia Plantarum, 129: 542-554. doi:10.1111/j.1399-3054.2006.00833.x.

Kuhlmann, U., Dosdall, L.M., and Mason, P.G. 2002. Ceutorhynchus obstrictus (Marsham), cabbage seedpod weevil (Coleoptera: Curculionidae). In Biological control programmes in Canada, 1981-2000. Edited by P.G. Mason and J.T. Huber. CABI Publishing, Wallingford, Oxon, United Kingdom. pp. 52-58.

Kuhlmann, U., Mason, P.G., Hinz, H.L., Blossey, B., De Clerck-Floate, R.A., Dosdall, L., et al. 2006. Avoiding conflicts between insect and weed biological control: selection of non-target species to assess host specificity of cabbage seedpod weevil parasitoids. Journal of Applied Entomology, 130: 129-141. doi:10.1111/j.1439-0418. 2006.01040.x

Larina, S.Y. 2003. Cardaria draba (L.) Desv. -Heartpodded hoary cress [online]. Available from http:// www.agroatlas.ru/en/content/weeds/Cardaria_ draba/ [accessed 4 April 2011].

Lefol, E., Danielou, V., and Darmency, H. 1996. Predicting hybridization between transgenic oilseed rape and wild mustard. Field Crops Research, 45: 153-161. doi:10.1016/0378-4290(95)00067-4.

Louda, S.M., Pemberton, R.W., Johnson, M.T., and Follett, P.A. 2003. Nontarget effects: The Achilles' heel of biological control? Retrospective analyses to reduce risk associated with biocontrol introductions. Annual Review of Entomology, 48: 365396. doi:10.1146/annurev.ento.48.060402.102800.

Moss, E.H. 1959. Flora of Alberta. University of Toronto Press, Toronto, Ontario.

Muller, F.J. 2006. Ensuring the safety of classical biological control for cabbage seedpod weevil in Canada: assessment of the ecological host range of candidate ectoparasitoids in Europe and clarification of their taxonomic status. Ph.D. thesis, University of Göttingen, Göttingen, Germany.

Muller, F.J., Baur, H., Gibson, G.A.P., Mason, P.G., and Kuhlmann, U. 2007. Review of the species of Trichomalus (Chalcidoidea: Pteromalidae) associated with Ceutorhynchus (Coleoptera: Curculionidae) host species of European origin. 
The Canadian Entomologist, 139: 643-657. doi:10.4039/n06-059.

Mulligan, G.A., and Findlay, J.N. 1974. The biology of Canadian weeds. 3. Cardaria draba, C. chalepensis, and $C$. pubescens. Canadian Journal of Plant Science, 54: 149-160. doi:10.4141/cjps74024.

Schwarzlaender, M., McKenney, J., and Cripps, M. 2002. Biocontrol pre-release studies on hoary cress in Idaho, adjacent states, and central Europe. Progress Report, Department of Plant, Soil, and Entomological Sciences, University of Idaho Moscow, ID 83844-2339, United States of America.

Simberloff, D. 2005. The politics of assessing risk for biological invasions: The USA as a case study. Trends in Ecology and Evolution, 20: 216-222. doi:10.1016/j.tree.2005.02.008.

Simberloff, D., and Stiling, P. 1996. How risky is biological control? Ecology, 77: 1965-1974. doi:10.2307/2265693.

Stiling, P. 2004. Biological control not on target. Biological Invasions, 6: 151-159. doi:10.1023/ B:BINV.0000022130.54793.b7.

Stiling, P., and Simberloff, D. 2000. The frequency and strength of nontarget effects of invertebrate biological control agents of plant pests and weeds. In Nontarget effects of biological control. Edited by P.A. Follet and J.J. Duan. Kluwer Academic Publishers, Norwell, United States of America. pp. 31-43.
Thomas, P. 2002. Canola growers' manual [online]. Available from http://www.canolacouncil.org/ canola_growers_manual.aspx [accessed 4 April 2011].

Thomas, M.B., and Willis, A.J. 1998. Biocontrolrisky but necessary? Trends in Ecology and Evolution, 13: 325-329. doi:10.1016/S0169-5347(98) 01417-7.

Thompson, W.R. 1955. Section 2: Host parasite catalogue, Part 3: Hosts of the Hymenoptera (Calliceratid to Evaniid). In A catalogue of the parasites and predators of insect pests. Commonwealth Agricultural Bureaux. The Commonwealth Institute of Biological Control, Ottawa, Ontario.

Vidal, S. 1997. Determination list of entomophagous insects. No. 13. Bulletin Section Regionale Ouest Palaearctique, Organisation Internationale de Lutte Biologique, 20: 1-25.

Williams, I.H. 2003. Parasitoids of cabbage seed weevil. In Biocontrol of oilseed rape pests. Edited by D.V. Alford. Blackwell Science, Oxford, United Kingdom. pp. 97-112.

Wittenberg, R., and Cock, M.J.W. 2001. Invasive alien species: a toolkit of best prevention and management practices. CABI Publishing, Wallingford, Oxon, United Kingdom.

Wright, M.G., Hoffmann, M.P., Kuhar, T.P., Gardner, J., and Pitcher, S.A. 2005. Evaluating risks of biological control introductions: a probabilistic risk-assessment approach. Biological Control, 35: 338-347. doi:10.1016/j.biocontrol.2005.02.002. 